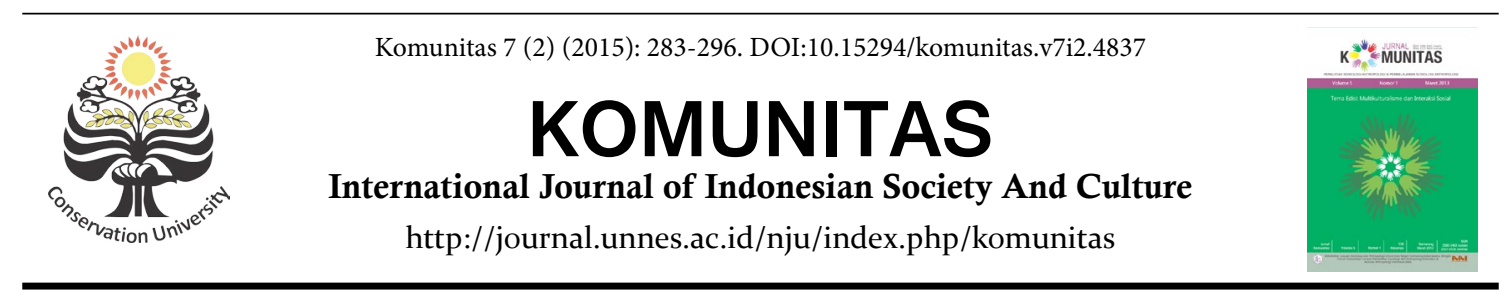

\title{
The Ethnography of Kerinci
}

\author{
Asvic Helida ${ }^{1 凶}$, Zuhud EAM ${ }^{2}$, Hardjanto ${ }^{3}$, Y. Purwanto ${ }^{4}$ and Agus Hikmat ${ }^{5}$ \\ ${ }^{1}$ Program Studi Konservasi Biodiversitas Tropika, Institut Pertanian Bogor, Bogor, Indonesia \\ ${ }^{1}$ Universitas Muhammadiyah Palembang, Indonesia \\ ${ }^{2}$ Tropical Biodiversity Conservation, Institut Pertanian Bogor, Indonesia \\ ${ }^{3}$ Forest Management, Institut Pertanian Bogor, Indonesia \\ ${ }^{4}$ Indonesian Institute of Science (LIPI), Indonesia \\ ${ }^{5}$ Tropical Biodiversity Conservation, Indonesia
}

Permalink/DOI: http://dx.doi.org/10.15294/komunitas.v7i2.4837

Received : August 2015; Accepted: September 2015; Published: September 2015

\begin{abstract}
Ethnography is an activity to describe and explain the culture of a society either in the past or the present which is presented in the form of descriptive narrative, covering the history of the origins, general state of location, location of the village and settlement patterns, language, family structure and composition of population, technological systems and equipment, knowledge systems, livelihood systems, religion/belief as well as art and traditional ceremonies. This study aims to describe ethnographic society in Kerinci which is one of the indigenous people in Indonesia who live in Kerinci Regency Jambi Province. People of Kerinci have a unique characteristic in culture both in terms of language, livelihood systems, knowledge systems, religions or beliefs system and art and traditional ceremonies. The data was collected through observation and participatory documentation study through interviews with the people based on everyday life of Kerinci community for 8 months from October 2013 to May 2014. The study sites were Baru Lempur Hamlet Gunung Raya District, Lama Tamiai Hamlet, Batang Merangin District and Ulu Jernih Hamlet Gunung Tujuh District. The data was analyzed qualitatively through the stages of data collection, transcription of data, categorization of data, temporary inference, triangulation and the final conclusion which was then presented in the form of a descriptive narrative. Data analysis was carried out in the field according to the context or situation that occurred when data was collected. The study results show that Kerinci community has unique and distinct characteristics, considering their elements of ethnography. In the case of language, they have their own script called 'incung', have a system of sociocultural values which are typical, have art and traditional ceremony called 'Kenduri Sko' as well as the system of knowledge on natural resources and biodiversity especially the plants.
\end{abstract}

Keywords: ethnography; kerinci community; baru lempur hamlet; lama tamiai hamlet; ulu jenrih hamlet;incung script; sko ceremony

\section{INTRODUCTION}

By definition, ethnography means writings or reports of a tribe that is written by an anthropologist based on the results of fieldwork for a period of months or years. Meanwhile, according to the terminology of language, ethnography is derived from the word ethnos, which means the nation and graphi which means writing. Therefore, ethnography means writing about the nations. And definitively, some experts provide limitations on ethnography as an activity which describes and explains a cultural community either in the past or present time (Sprad- ley 1997). Some other opinions express ethnography as a description of the culture of a nation that includes language, technology system, economics, social organization, knowledge systems, art and religious system (Koentjaraningrat 2009).

Another perspective states that ethnography is basically research activities to understand the way people interact and work together through the phenomenon which is observed on a daily basis (Genzuk 2003). Hence, ethnography aims to describe a culture as a whole, i.e. all aspects of the culture including material culture such as artifacts,

(C) 2015 Semarang State University. All rights reserved p-ISSN 2086 - 5465 | e-ISSN 2460-7320
Address: Jl. Jend. A.Yani No.13 Palembang

Email : saktiintan@yahoo.co.id 
and also abstract culture such as experience, tnorms and value system of the studied group. Ethnography is useful to examine the behavior of human beings in a specific natural environment. Thick description based on the participatory observation is the main characteristic of ethnography. The observations involve emphasis on logic of discovery, a process which aims at suggesting concepts or construct theories based on real human reality.

Ethnographic study was originally undertaken to establish the development levels of human cultural evolution from the first time human emerged on the surface of the earth to the current period. But on further development, ethnography is more focused on contemporary life, which is about the way of life of the community. Ethnographic goal is to describe and build social as well as cultural structure of a society (Spradley 1997).

According to Spradley (1997), in addition to cultural studies, ethnography is also a learning process that can be used to interpret the surrounding world and devise strategies to deal with the behavior. In this view, Spradley no longer regards ethnography as a method to study the other culture (small people) that is isolated, but also our own society, multicultural communities around the world. Spradley insists that ethnography must be about the nature of culture, which is as acquired knowledge to interpret the experience and delivery of social behavior. That is why ethnography will reveal the entire socio-cultural behavior through a holistic description. The same claim is confirmed by Salvador (1999) and Ibn Khaldum (2000), that the social behavior of a group or class culture is greatly influenced by ethnography of the society.

Indonesia is the third mega-cultural country after Papua New Guinea and India (Mangunjaya 2005), which is reflected by the diversity of cultures, languages, natural resource management systems and agricultural systems. Ancient (1991) says that there are 550 indigenous tribes living in Indonesia and spreading from Sabang to Merauke and one of them is indigenous people of Kerinci.
Kerinci society is one of the indigenous people who live in Kerinci Regency, Jambi province. They have unique characteristics that have not been widely studied. Since long time ago, Kerinci community has had its own script language, diverse dialects, system of art and unique traditional ceremonies, knowledge system. Besides, their system of kinship/family is still strong.

In 1996, there was a change in the policy, regulating forest in Kerinci Seblat to be a conservation area and National Park by decree of the Minister of Forestry No. 192 / Kpts / II / 1996. The designation of conservation area Taman Nasional Kerinci Seblat TNKS causes most of the Kerinci regency is included in TNKS region (51.2\%). This leads to changes in the value system and characteristics of Kerinci community. Therefore, the ethnographic study on Kerinci society emerges as an interesting topic of research. The purpose of this study is to reveal the ethnography of Kerinci community which includes the general situation of location, language, knowledge system, religion/belief, art systems and traditional ceremonies as well as to analyze the changes before and after the establishment of TNKS area.

\section{RESEARCH METHODS}

The study was conducted in three locations within Kerinci Regency, Jambi Province namely Baru Lempur Hamlet, Gunung Raya District, Lama Tamiai Hamlet Batang District, and Ulu Jernih Pelompek Hamlet, Gunung Tujuh District. The study lasted for 8 eight months starting from October 2013 until May 2014 (Figure 1).

The collected data included the general condition of the research location, language, structure and composition of the population, system of equipment and technologies, system of knowledge, system of livelihood, religion/belief, traditional ceremonies and art that exist in Kerinci community. Data collection technique used descriptive qualitative approach using desk study (study documentation) of history and participatory observation through interviews with informants consisting of traditional leaders, community leaders, and agents 


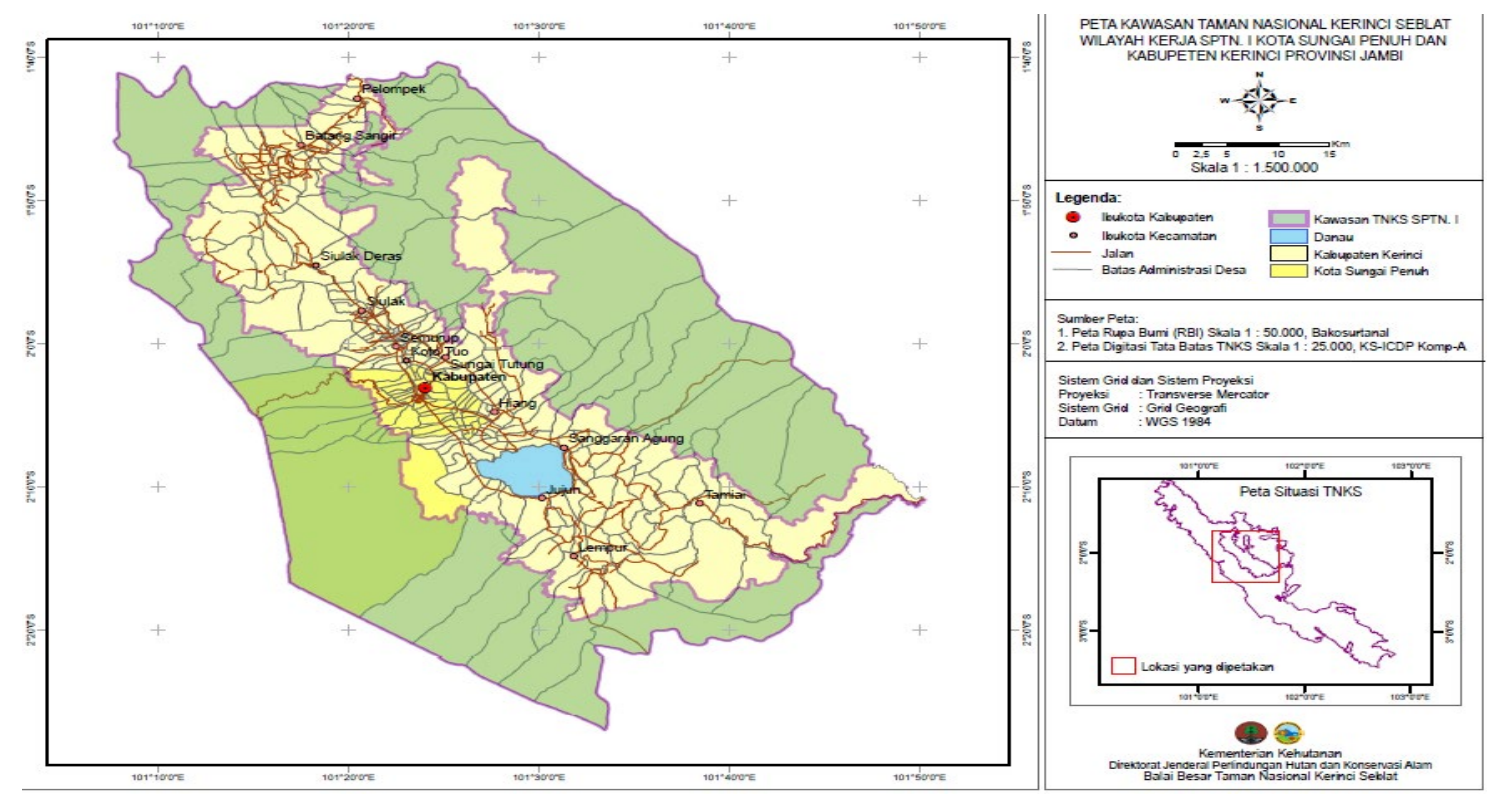

Figure 1: Research Location Map

of history determined by a snowball technique. The data which had been collected was then analyzed qualitatively through the stages of data collection, transcription of data, categorization of data, temporary inference, triangulation, and final conclusion. The data was presented in a descriptive narrative form. Data analysis was carried out in the field according to the context or situation that occurred at the time when the data was collected (Irawan 2006; Lapau 2012).

\section{RESULTS AND DISCUSSION}

Yakin (1986) mentions that the origin of the name "Kerinci" comes from several opinions. The first opinion states that a figure named Datuk Paduko Berhalo who lived in lakeside Kerinci (now becomes Sanggaran Agung Village) lost a key that fell into the river and struggled to find it. He finally got his key back so he named the river with Batang Kunci (key) which later became popular with the name of Batang Kerinci ("batang" in local language means river).

The second opinion states that Kerinci comes from the Javanese word means "kering (dry)" and "ci" which means dry river. From "keringci", it later became "kerinci". The third opinion mentions that as Kerinci area lies on a plateau surrounded by the
Bukit Barisan, in the summer, it is "kering (dry)" and in the rainy season it is "cair" (liquefied)" so that it becomes "kering cair (dry liquid)" which was later changed into "kerinci". The fourth opinion states that according to its natural state, it is lined by hills ranging from the north to south with peaks accompanied by dense forest. Because the area is difficult to pass, causing this area is confined and makes it very difficult as "locked (terkunci)", which eventually became the word "kerinci".

Dealing with the origins of indigenous people of Kerinci, there are several opinions. The first opinion states that indigenous peoples came from the back of India (Southeast Asia) and Mongolia who came along with the arrival of nations that spread throughout the archipelago. They arrived in Kerinci through the Malay Peninsula (now Malaysia), crossing the Malacca Strait, went down to the east coast of Sumatra to the south, veering into the Batang Hari River, continued to Merangin Batang River and went up into the upper, reaching the present Kerinci area. After reaching the area, there had been people who were inhabit ing the place but their origin was unknown. This opinion reinforces the notion that indigenous people in Kerinci are older than the 
Incas of America, who had existed since the days of Paleothikum (Zakaria 2012)

The second opinion states that the origin of indigenous people of Kerinci came from Papua Melaneoid a half million years ago. The remaining descendants of this tribe in Indonesia are still found living in the hinterland areas such as the Kubu Tribe in hinterland of Sumatra and the Pagai Tribe in Mentawai island. But in Kerinci, the tribe has been extinct or allegedly, they were spread further into another hinterland of Sumatra (Zakaria 2012).

The third opinion (Disparbud 2004) mentions that the arrival of Kerinci tribe happened during nirleka which was during Paleolithicum and Mesolithicum eras approaching the 10,00o years BC. Meanwhile, in the age of Neolithikum, Kerinci tribe came two waves from Yunnan region of China namely Malay Austronesian ethnic. Their arrival waves are:

a. The first wave is ethnic Proto Malay (Melayu Tua), which came in the year of 6000 to $2000 \mathrm{BC}$ during the Old Stone Age.

b. The second wave is Dento ethnic Malay (Melayu Muda) around 2000-3000 BC, which lasted from the Young Stone Age to the Bronze Age (metal).

Based on the results of interviews with prominent cultural of Kerinci, Mr. Zakaria Iskandar, the most-widely accepted opinion on the origins of the people of Kerinci is the first opinion that Kerinci people came from the Indian Rear (Southeast Asia) and Mongolia, which came along with the nations who spread to all corners of the archipelago.

General Situation of Research Sites

Kerinci Regency which is also called "Sakti Ala Kerinci" is a highland area that is surrounded by Southern Bukit Barisan, located in western area of Jambi Province within $\pm 450 \mathrm{~km}$ from the provincial capital, lying at the altitude of 450 to $1500 \mathrm{~m}$ above sea level.

Geographically, it is located at 101008 '- 101 050' BT and 1041 '- 2026' LS and has borders in the north with Solok District West Sumatra province, in the south with Sarko District Jambi Province and on the
North with Bengkulu Bengkulu province, in the east with Bungo Tebo District Jambi Province, and in the west with Pesisir Selatan Regency West Sumatra Province.

Generally, Kerinci Regency is an area with specific characteristics of valleys and hills. Kerinci valley has deposition area of $3808.50 \mathrm{~km} 2$ so that it looks as if Kerinci is a "giant bowl". Kerinci Lake in the south and Mount Kerinci with an altitude of $3805 \mathrm{~m}$ above sea level in the north and the gentle slopes of the valley are the small stretch of hills. On the north side, there is also a lake of Mount Tujuh which is the highest lake in Southeast Asia.

Kerinci has tropical climate with an average temperature of $21.9^{\circ} \mathrm{C}$ with a maximum temperature of $28.9^{\circ} \mathrm{C}$ occurs in May and minimum temperature of $16.6^{\circ} \mathrm{C}$ in February. Kerinci has various soil types. Among them are volcanic soil which is very fertile, the mountain ground with mild slope containing inseptisol and ultisol which are relatively infertile, with a thin layer of fertile soil, but easily eroded, and land with volcanic rocks of acid in the Merangin valley and sediment soil in the bottom of the valley (BPS 2012).

In particular, the three study sites are hamlets which are located in the rural village and directly adjacent to the Kerinci National Park area. These hamlets have different characteristics and biophysical society. Community characteristics including accessibility, socioeconomic, ethnic diversity (ethnic) community and community residential distance to the Kerinci National Park area are presented in table 1. And the biophysical conditions including geomorphology, altitude, rainfall, soil type, farming conditions, and region classification based on geomorphological conditions are presented in table 2.

Table 1 shows the differences in the accessibility of different hamlets, Baru Lempur Hamlet has a relatively low accessibility, while Lama Tamiai Hamlet and Ulu Jernih Hamlet are high. The accessibility of the study refers to the level of transportation and mobility ease to the capital of Kerinci, Sungai Penuh City. 
Table 1 : Social Characteristics of Study Sites

\begin{tabular}{llll}
\hline \multicolumn{1}{c}{ Characteristics } & \multicolumn{1}{c}{$\begin{array}{c}\text { Baru Lempur } \\
\text { Hamlet }\end{array}$} & \multicolumn{1}{c}{$\begin{array}{c}\text { Lama Tamiai } \\
\text { Hamlet }\end{array}$} & Ulu Jernih Hamlet \\
\hline Accessibility & Low & Medium & High \\
Socio-economy & High & Low & Medium \\
Distance to TNKS & Far & Medium & Near \\
Etnicity/tribe & Original Kerinci & High mixture & Medium mixture \\
\hline
\end{tabular}

Table 2 : Geomorphological Characteristics of Study Site

\begin{tabular}{|c|c|c|c|c|}
\hline No & $\begin{array}{l}\text { Biophysical } \\
\text { Aspects }\end{array}$ & $\begin{array}{c}\text { Gunung Tujuh Sub- } \\
\text { District }\end{array}$ & $\begin{array}{c}\text { Batang Merangin Sub- } \\
\text { District }\end{array}$ & $\begin{array}{c}\text { Gunung Raya Sub- } \\
\text { District }\end{array}$ \\
\hline 1 & $\begin{array}{l}\text { Geomor- } \\
\text { phology }\end{array}$ & hills and mountains & $\begin{array}{l}\text { Hills with flat and plain } \\
\text { valley floor }\end{array}$ & Ground and hills \\
\hline 2 & Altitude & $>1000 \mathrm{~m}$ asl & $500-1000 \mathrm{~m}$ asl & $100-\geq 1000 \mathrm{~m}$ asl \\
\hline 3 & Rainfall & $\begin{array}{l}1500-2000 \mathrm{~mm} / \\
\text { year }\end{array}$ & $\leq 1500 \mathrm{~mm} /$ year & $2000-5000 \mathrm{~mm} /$ year \\
\hline 4 & Soil Type & Andosol, latosol & $\begin{array}{l}\text { Andosol, latosol, pod- } \\
\text { solik, aluvial }\end{array}$ & $\begin{array}{l}\text { Andosol, latosol, pod- } \\
\text { solik, litosol }\end{array}$ \\
\hline 5 & Agriculture & $\begin{array}{l}\text { Main agriculture is } \\
\text { vegetables and agro- } \\
\text { forestry of cinna- } \\
\text { mons, limited wet- } \\
\text { land area. }\end{array}$ & $\begin{array}{l}\text { Main agriculture is } \\
\text { paddy, limited field } \\
\text { area in the hillside. }\end{array}$ & $\begin{array}{l}\text { Main agriculture is } \\
\text { cinnamons and other } \\
\text { plantations, especially } \\
\text { monoculture planta- } \\
\text { tions, there are some } \\
\text { agroforestry of cinna- } \\
\text { mons. }\end{array}$ \\
\hline 6 & $\begin{array}{l}\text { Regional } \\
\text { classification }\end{array}$ & Plateau of Kayu Aro & $\begin{array}{l}\text { Middle area of Kerinci } \\
\text { Valley }\end{array}$ & Areal Lolo- Lempur \\
\hline
\end{tabular}

Dealing with socio-economic, based on the available information and data, Baru Lempur Hamlet community has a high socioeconomic level, Lama Tamiai Hamlet is low and Ulu Jernih hamlet is medium. The distance to the Kerinci National Park in this research refers to the distance of residential communities to national park which are distinguished by category of "far" (> $5 \mathrm{~km})$, "medium" (2-5 km) and "close" (0-2 km). The ethnic or tribal people are categorized based on their tribe or ethnic origin. The majority of Baru Lempur people are indigenous tribe of Kerinci (95\%), Lama Tamiai Hamlet people are categorized as high mixture because the society consists of partial Kerinci origins (45\%), and other tribes (55\%) such as Minang, Javanese, Bugis and Batak, while people in Ulu Jernih Hamlet are categorized as medium mixture because the people are still dominated by Kerinci Tribe (75\%) and the other tribes (25\%) such as Minang and Javanese.

Table 2 shows that the three study sites have different geomorphological altitude, rainfall, soil type, agriculture and regional classifications based on its geomorphology. Ulu Jernih Hamlet in Gunung Kerinci Sub-district has geomorphology of hills and mountains with altitude above $1000 \mathrm{~m}$ above sea level, rainfall 1500-2000 $\mathrm{mm} /$ year. Lama Tamiai Hamlet in Batang Merangin Sub-district has geomorphology of valley with hills and sloping terrain with altitude 500 - $1000 \mathrm{~m}$ above sea level, rainfall $\leq 1,500 \mathrm{~mm} /$ year. Baru Lempur Hamlet in Gunung Raya Sub-district has geomorphology of plain grounds and hills with altitude 100 - $1000 \mathrm{~m}$ above sea level and precipitation $2000-5000 \mathrm{~mm} /$ year. 


\section{The Layout of Hamlets and Settlement Patterns}

Based on the results of field study, the ancestors of Kerinci people always made the settlements in areas that have fertile and good environment. Urban centers are then grown and expanded from the smallest unit which they call as "Talang." Talang is settlement that usually consists of 5-10 houses located in the area of cultivation for one family or referred to as "Tumbi." Within one Talang, the distance between one house to another is still far away. The interaction and communication among people is still limited, between one and the other Tumbi still has not integrated yet as a unified society.

The development of the population from some Talang creates Tumbi and new agricultural lands. The increasing number of Tumbi, both from Talang population and from another community definitely requires a new settlement. At such conditions, the consensus emerges among them to establish a location in the vicinity of fields that are considered worthy to serve as the central settlement. This location can be developed from existing Talang or by choosing a new location that is strategically considered worthy to be the center of the settlement. Gradually they build dwelling houses, thus forming larger groups of people.

Residential center which is formed by the group in a Talang consisting several Tumbi is called "Koto." Development of Koto will gradually improve the status of Koto into a "Kampung " and further developed into a "Dusun." The centers of settlements of the ancestors of Kerinci which are called as "talang", "koto", "kampung" and "dusun" are generally located in areas of fertile grounds around rivers and lakes.

This still can be seen in the Baru Lempur Hamlet. The hamlet which is known as Lekuk Lima Puluh Tumbi is located in the fertile ground close to river. Baru Lempur Hamlet is a village with almost all the population (95\%) are indigenous people of Kerinci. The settlement with clustered pattern is still the characteristic of the Baru Lempur Hamlet community in Gunung Raya District(Figure 2).

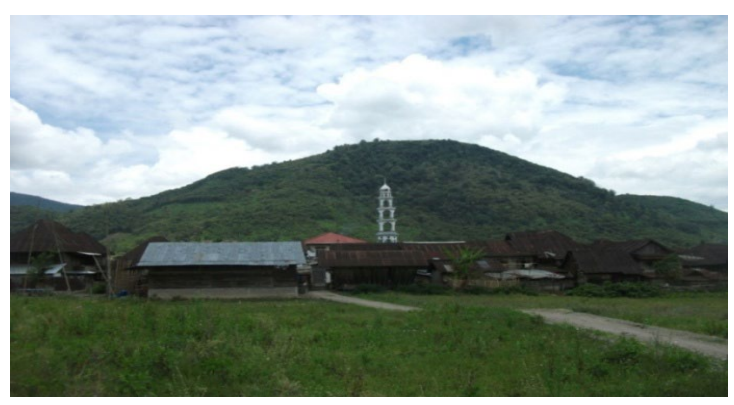

Figure 2: The pattern of settlement of indigenous people in Baru Lamper Hamlet (Source: Research 2013)

Figure 2 shows that the settlement patterns of Kerinci indigenous people which is clustered in a residential area called dusun (hamlet) or talang in the circle of "parit bersudut empat, di katup lawing "deco." It means that the house is built on flat land with house types are built in relatively close so it looks like one long building. This type of residential community is also called "laheik nan bajago-lamang nan basepea " which means the lined house that is swept consisting several houses which usually still have a very close genetic relationship (Figure $3 a$ ).

This lined houses are connected one to another, resembling a stage which consists of stairs, "palasa', outer space (Figure 3b) that serves as conferring space tengganai (dunsanak mother) or it is called "unding umah Dalea" and a space which serves for a family break. In outer space there is "anjung" floor which is slightly raised approximately a finger inch.

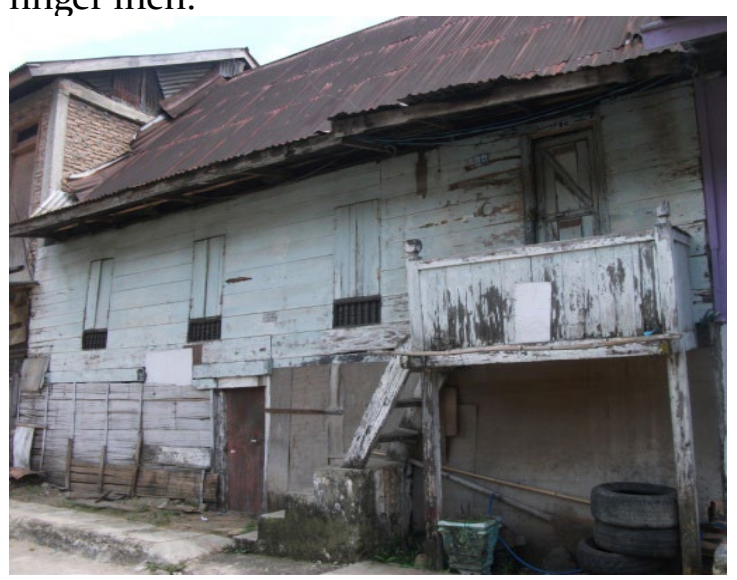

(3a) 


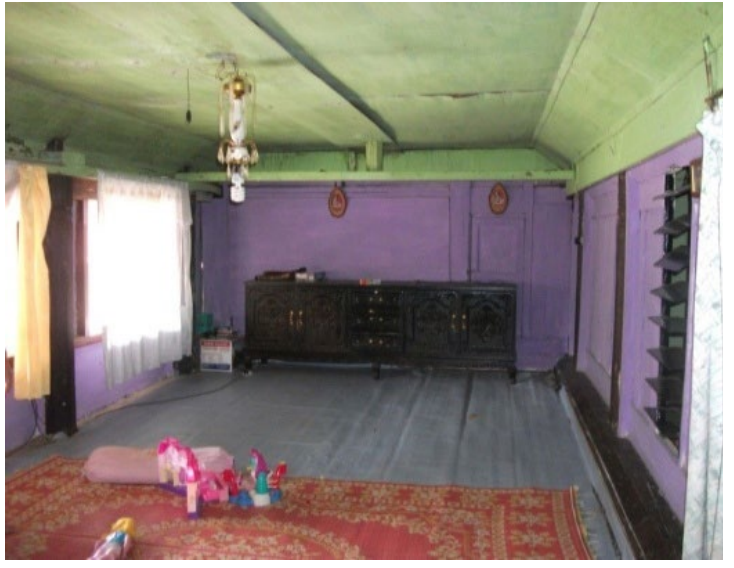

(3b)

Figure 3: The original of lined house (= umah strip) from Kerinci (za) and outer space "unding umah Dalea" (3b)

The existence of umah larik is hard to find although traditionally, umah $l u-$ rik exists in every village. Several factors lead to the loss of tradition on umah lurik, both because of society and natural factors such as earthquake and fire. Besides disaster reasons, factors on owner convenience, privacy and hygiene are the cause of people leaving umah larik tradition and starting to build individual houses.

The difficulties in obtaining wooden material and the influence of modern style houses are the reasons of people to prefer having a permanent house and leaving the tradition of building houses from timber. The construction of permanent house is more efficient in terms of cost.

On the home yard (= laman), indigenous Kerinci people have "lumbung padi (paddy barn)" which is used to store rice after the harvest. The barn lasts until the harvest time next year, even up to many upcoming years. The barn is made of wood with average size ( $4 \times 6) \mathrm{m}$, has a door made high by using a ladder for entering and removing rice (Figure 4 ).

The oldest barn was built in the $1900 \mathrm{~s}$ and has been used by three generations. This barn can last long, and now its condition is still strong because it uses best quality woods such as ironwood /unglen (Eusideroxylon zwageri) which is obtained from the surrounding forest. Currently the barns are no longer used as a store of rice, because people prefer to store paddy "rice milling" because of ease of use and time efficiency.

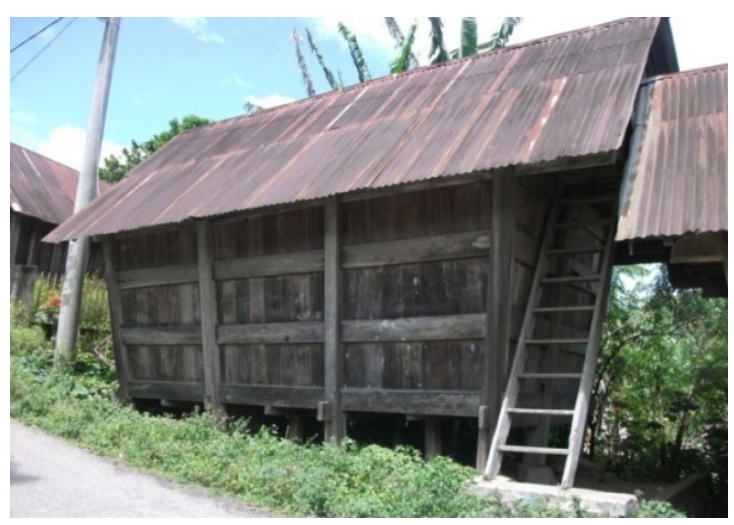

Figure 4: Kerinci indigenous rice barn in Baru Lempur Hamlet (Source: Research 2013)

The people of lama Tamiai Hamlet and Ulu Jernih Hamlet are people of Kerinci who have experienced assimilation with other tribes such as Minang, Javanese, Bugis and Nusa Tenggara. The assimilation that occurs along with the other social factors causes the old model of settlement to be obsolete. The settlement pattern that used to be one long building, is then transformed into individual houses of modern style.

Based on the results of interviews conducted with community leaders, they mention that umah larik has a valuable meaning which reflects coherence, familiarity, awareness, togetherness and openness from the philosophy of the indigenous Kerinci communities in developing the country. As revealed in Kerinci society by this rhyme:

"Bukit Kerman berladang padi,orang Lolo bertanam jarak, padi habis dimakan rusa, negeri aman padi menjadi, rumput muda ternaknya banyak, aman sentosa negeri ini" atau "Muko pasar babelok, tanam mangkari dalam padi, gotong royong membawa elok, negeri aman padi menjadi”.

\section{Language of Kerinci Community}

The language of Kerinci community is different from the language of other regions in Sumatra, but it still belongs to the Old Ma- 
lay language (Austronesia) which is spoken in Kerinci dialect. This difference is caused by the remote location of Kerinci area that has its own dialect. The dialect is different from the other tribes of Sumatra, but in general, they will understand Malay or Indonesian. Characteristics of Kerinci language is seen on several dialects, each region has a different dialect.

Based on the results of the study, it shows that every native hamlet in Kerinci has its own dialect ( \pm 177 dialects according to the amount of the original village). Among the factors that lead to the differences in dialect is, the territorial genealogical relationship is more dominant, even though neighboring village is limited only by road or river. Dialect differences do not cause communication between the hamlets being hampered, because they mutually understand other dialects as well.

These dialect differences are also marked by cultural differences that exist in each hamlet of Kerinci. Such as the pronunciation of 'Anda/you', in Baru Lempur Hamlet, it is pronounced as 'kaya,' in Sungai Penuh District it is pronounced with 'kayo.' The table 3 below shows some examples of words to compare Kerinci language with other languages.

In addition to the different dialect in every native village, Kerinci also has their own alphabets or letters with a script called Incung (Disparbud 2003). Incung script has been used by the ancient people of Kerinci and has a distinctive shape. The existence of Incung script can be found in some old documents of Kerinci community. Incung characters are formed by straight lines, broken truncated arches and curved lines in some particular letters and there are only few letters. The slope of the lines forming the letters is an average of $45^{\circ}$, so the letters are not written in italic like the writing in Latin script.

Incung script has long been used by the people of Kerinci. This can be seen in ancient texts that are found such as the ancient manuscripts of Pusako Rajo Sulah in Siulak Mukai Village. These manuscripts have classical value both in terms of forms, stationery and the media that are used. However, Incung scripts cannot be classified based on the period of time because Incung script does not include the time of its creation and author (Disparbud 2003).

The table 3 shows a few examples of the use of Kerinci words. The dialect is still used today, namely the use of the letter ' $\mathrm{i}$ ' at the end of a word which is pronounced as 'ai' like Kerinci becomes Kerincai or Kincai and 'Kami' becomes 'Kamai'. The letter ' $r$ ' is usually pronounced 'ha' if the final word is ' $r$ ' for example 'kemari' becomes 'kamahai'.

Table 3: Examples of differences in Kerinci language with other languages

\begin{tabular}{llll}
\hline \multicolumn{1}{c}{$\begin{array}{c}\text { Indonesian } \\
\text { Language }\end{array}$} & \multicolumn{1}{c}{$\begin{array}{c}\text { Minang Kabau } \\
\text { Language }\end{array}$} & \multicolumn{1}{c}{$\begin{array}{c}\text { Jambi } \\
\text { Language }\end{array}$} & \multicolumn{1}{c}{$\begin{array}{c}\text { Kerinci } \\
\text { Language }\end{array}$} \\
\hline Kerinci & Kurinci & Kerinci & Kincai, Kinci \\
Sungai Penuh & Sungai Panuah & Sungai Penuh & $\begin{array}{l}\text { Sunge Penoh } \\
\text { kayou }\end{array}$ \\
kaya & "rang kayo & kayo & basuou \\
berjumpa & bajumpo & berjumpo & mendah \\
tamu & tamu & tamu & dudeuk \\
duduk & duduak & duduk & lao, lun \\
belum & alun & belun & kamahai \\
kemari & kamari & kemari & suhat \\
surat & surek & surat & lupouk \\
luput & lupuik & luput & uhang \\
orang & urang & orang & ikoa \\
kamu & waang & kau & nantan, nanggut \\
kakek & inyiak & datuk & kamai \\
kami & kami & kami &
\end{tabular}

(Source: Primary data, 2014) 


\section{Family Structure and Population Com- position}

The prevailing family structure is an interesting line from bottom to top Pulai yang bertingkat naik, meninggalkan ruas dengan buku, manusia yang bertingkat turun meninggalkan anak dengan cucu, waris dengan pusako : Each of the generation line has a different name (Figure 5)

Figure 5 shows that seven offspring from the bottom to the top has different names, while more than that seven above is called as 'nenek muning'.

The indigenous people of Kerinci follow the lineage of the 'mother' or known by the term 'matrilineal' or 'matriarchal'. Matrilineal descent implies that people recognize the family line according to maternal line. In the family, a father is an outside of family of child and wife, the father is called as 'orang semenda ' or also called as 'anak betino ' from the family of mother's siblings. Brother of the man's wife is called 'Tengganai' who plays the role of the council as the supreme consideration in the family 'batih'. He is called 'mamok' (= mother, uncle). $M a-$ mok is the one who receives the power from the mother to arrange the house. Like the proverb in Kerinci 'Rumah sekato tengganai, luhak sekato penghulu, alam sekato rajo'

For the composition of the population by sex and age structure, it shows that the number of male is more than female, except in Baru Lempur Hamlet which shows the number of female is more than male (Table 4).

Table 4 shows the population in the three study sites based on data from the 2012 village potential in each study site. Baru Lempur hamlet is the most populated hamlet with a population of 1031 people consisting of 492 males and 521 females. The second is Lama Tamiai Hamlet with 910 people and Ulu Jernih Hamlet with 875 people.

As for the age composition of the population that is distinguished by five age classes (AC) is as follows: AC I <24 years, AC

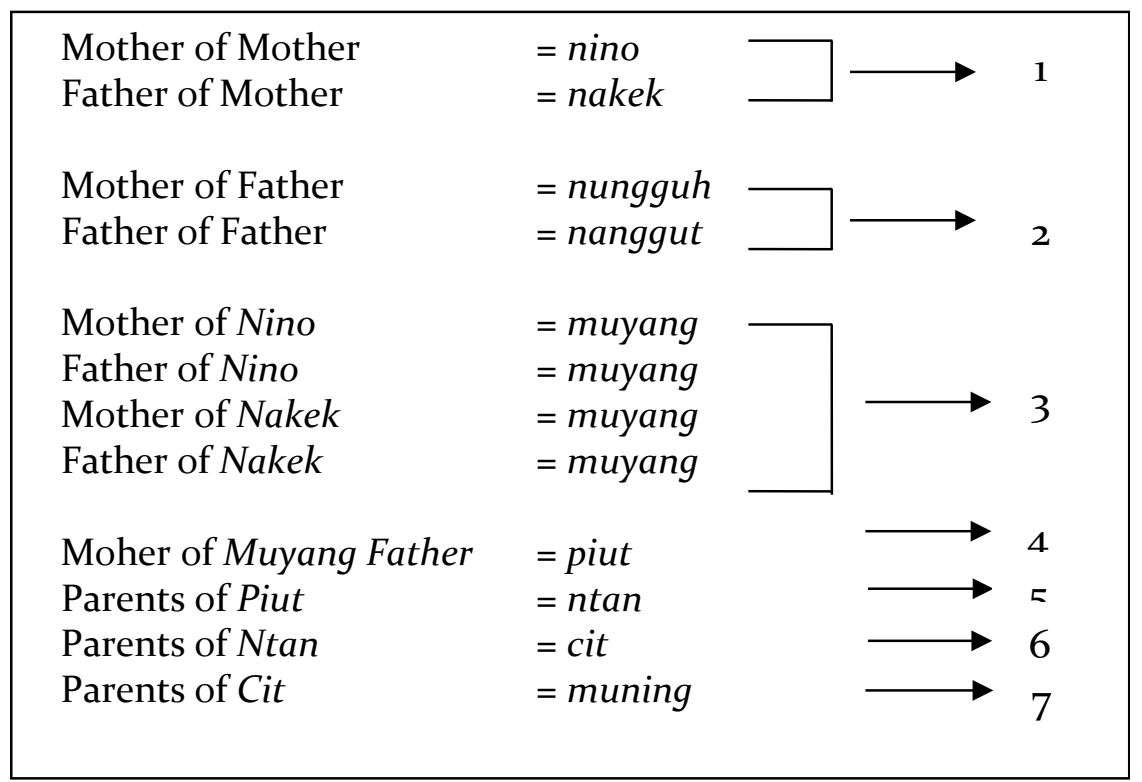

Figure 5: Structure of kinship Kerinci (Source: Yakin, 1986)

Table 4: Composition of Population Research Society in 3 study sites

\begin{tabular}{lrrrr}
\hline \multicolumn{1}{c}{ Study Sites } & \multicolumn{1}{c}{ Male } & \multicolumn{1}{c}{ Female } & Head of household & Total (people) \\
\hline Baru Lempur Hamlet & 492 & 521 & 320 & 1013 \\
Lama Tamiai Hamlet & 460 & 450 & 290 & 910 \\
Ulu Jernih Hamlet & 445 & 430 & 283 & 875 \\
Total & 1397 & 1401 & 893 & 2798 \\
\hline
\end{tabular}


II 25-39 years, AC III 40-54 years, AC IV 5569 years and $A C V>69$ years can be seen as the image 6 .

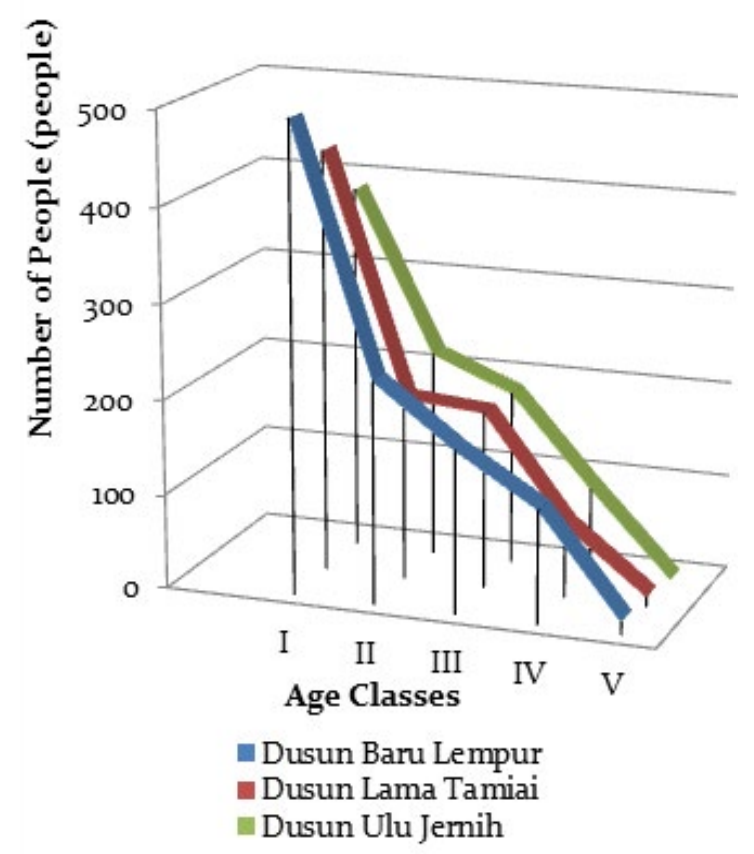

Figure 6: The composition of population based on age group

From Figure 6, it shows that the composition of age group for the three study sites is almost the same which follows the chart of normal growth depicting the age class I which is more than the other age classes. The next AC is decreased with AC V is the least with the members of the people aged over 69 years. For AC III in Lama Tamiai hamlets, there is an increase in the number of people. This is due to the age class of the many outsiders who later settle down and live there.

\section{Technology System and Equipment}

Technology systems in Kerinci society refers to the farming system which is their main occupation. Topographically, it is a suitable land for farming and plantation. With the rooted cultural area, traditional system is more advantageous to be used. Lowland rice farming system is done by using traditional technology. Water is flowed from a high place into the lower paddy fields. The lower water is raised by means of wheel-windmill by vessels of bamboo. But for now, waterwheel is rarely found. The upland rice farming system that does not allow water reservoirs is made in hilly lands.

In accordance with the lifestyle of Kerinci people which is farming, planting and agricultural, initially, equipment which is used is agricultural tools such as pick beliung, parang, axe, cangkul kayu dengan mata besi, bajak, sikat and tundo. To process the paddy into rice, they use kisa, lesung air and lesung batu. These tools have changed. The use of water or a stone mortar/lesung is left and switched to rice milling machine.

\section{Knowledge Systems of Kerinci People}

Kerinci community or uhang kincai is included in ethnic groups who have a philosophy of life, as well as the Minangkabau ethnic communities who have the philosophy of 'alam takambang jadi guru', Kerinci community also has a philosophy of nature-oriented life. Kerinci people's knowledge of the natural environment and natural resources can be seen from how they regulate the use of units of the environment and its resources (Aumeeruddy 1994; Devi 2012). They have split their surrounding units and know how to use it well. Changes in environmental unit through the adaptation process as lasted for generations and become a form of knowledge that they use.

In addition, Kerinci people have established close interaction with the surrounding forest. Forest, according to their perspective, is an inseparable part of life. Forest in a holistic sense implies economical, religious and socio-cultural components. The knowledge on the importance of forest especially as a backup storage of water, prevention of erosion and landslides is well understood by the people of Kerinci. They realize that they live in an area surrounded by hills just like a 'giant bowl' that is prone to landslides and floods. Forests for Kerinci society have become a source of livelihood; therefore it is important for them and should be maintained.

Kerinci people already have the knowledge of how to take advantage of the forest and forest products such as plants and animals. Forest plants are used for food sources, 
medicines, shelter and other uses. Animals there are also used as a source of food and medicine. Harvesting is regulated by customary law. Sustainable forest is a hope for the people of Kerinci. According to Kerinci people, sustainable forest management is to be able to meet the criteria of sustainability in economic, ecological and social aspects (Table 5).

In simple terms, the concept of sustainable forest management can be described as the attainment of balance between society's demand which is increasing for forest products, benefits, and preservation of forest health and diversity. Sustainability is very important to the survival and wellbeing of forest-dependent communities just

\section{like Kerinci people.}

\section{Livelihood system}

The main source of livelihood of Kerinci people is in the agricultural sector. The main strength of Kerinci district is the availability of potential resources. This natural resource potential is not only to be cultivated, but also to be preserved as a capital for specific activities such as tourism. The absence of the dominant industrial sector and the service sector leads to delay in the development of the agricultural sector which dominates the economy of Kerinci community.

In all three study sites, the majority of community members are engaged in the agricultural sector. Based on the field information, $90 \%$ of people in Baru Lempur Table 5: Criteria for Sustainable Forest Management According to Kerinci People

\begin{tabular}{|c|c|c|}
\hline Aspect & Criteria & Indicators \\
\hline Economy & $\begin{array}{l}\text { Sustainability } \\
\text { of economy } \\
\text { function }\end{array}$ & $\begin{array}{l}\text { The community can utilize non-timber forest products for the } \\
\text { purposes of everyday life. } \\
\text { Communities can take wood as an energy source of daily life } \\
\text { Communities can take and utilize timber as building materials }\end{array}$ \\
\hline Ekologi & $\begin{array}{l}\text { sustainability } \\
\text { of ecological } \\
\text { functions }\end{array}$ & $\begin{array}{l}\text { The availability of water source is sufficient to meet the needs of } \\
\text { daily life and irrigation for their agricultural purposes } \\
\text { Protection of mountain springs from any damage and disrup- } \\
\text { tion that can cause droughts or floods } \\
\text { proportion of protected forest area which serves both to the } \\
\text { overall area that should be protected and confirmed its exis- } \\
\text { tence is recognized by concerned parties } \\
\text { Protection of biological resources both plants and animals liv- } \\
\text { ing in the forest that can be utilized in a sustainable manner }\end{array}$ \\
\hline $\begin{array}{l}\text { Sosial bu- } \\
\text { daya }\end{array}$ & $\begin{array}{l}\text { Sustainability } \\
\text { of } \\
\text { Social and } \\
\text { cultural func- } \\
\text { tion. }\end{array}$ & $\begin{array}{l}\text { The recognition of indigenous forests / customary are well doc- } \\
\text { umented and protected } \\
\text { AThe presence of community participation in forest planning } \\
\text { and forest management practices based on economic activity } \\
\text { Minimal economic resources of community can continue to } \\
\text { support the survival of the community across generations }\end{array}$ \\
\hline
\end{tabular}

(Source: The results of the field, processed, 2014)

Hamlet are farmers. In Lama Tamiai Hamlet and Ulu Jernih Hamlet, respectively, $85 \%$ and $60 \%$ of people are farmers. The typical crop is cinnamon (Cinnamomum burmanii) as well as other agricultural products such as coffee, tea, potatoes, rice and vegetables. Their livelihood other than farming is by doing plantations. The other are working in fishery (fishing lake, livestock, and services sectors such as Civil Servant (PNS / TNI /
Polri), labors, motorcycles, and household industries.

In some previous years, the price of major commodities such as cinnamon, tea, coffee and cloves are declined sharply. This situation affects the public interest on farming so that more people in productive age in Kerinci work as migrant worker abroad such as Malaysia, Taiwan, Japan and Saudi Arabia (Table 6) 
Table 6: livelihood of people in three study sites

\begin{tabular}{lccc}
\hline \multicolumn{1}{c}{ Occupation } & $\begin{array}{c}\text { Baru Lempur } \\
\text { Hamlet (\%) }\end{array}$ & $\begin{array}{c}\text { LamaTamiai } \\
\text { Hamlet (\%) }\end{array}$ & $\begin{array}{c}\text { Ulu Jernih } \\
\text { Hamlet (\%) }\end{array}$ \\
\hline Farming & 90 & 85 & 60 \\
Plantation & - & - & 25 \\
Fishery & - & - & 5 \\
PNS/TNI/Polri & 5 & 5 & 5 \\
Other service works & 3 & 5 & 3 \\
Migrant workers & $\mathbf{2}$ & 5 & $\mathbf{2}$ \\
\hline
\end{tabular}

From Table 6, it shows that the majority of people in three study sites have occupation in the agricultural sector. There are $90 \%$ of people in Baru Lempur Hamlet work as farmers as their main livelihood. They have rice paddies and fields with good planting cycle. The rest is the civil servant / military / police, other services such as trading, electronic services, craftsmen, and some people who work abroad as migrant workers (TKI).

In Lama Tamiai Hamlet, there are 85\% of people who work in agriculture sector, the remaining people work as civil servants, TNI/Polri, other services such as trading and craftsmen, as well as migrant workers. In Ulu Jernih Hamlet, the majority of people come from other areas of Kerinci. $60 \%$ of its people are working in the agricultural sector, followed by plantation of $25 \%$ such as plantations of tea, coffee and cloves.

\section{Religion/Faith System}

The original inhabitants of Kerinci are followers of Islam. Islam in Kerinci is spread by migrants from other regions, mostly from Minangkabau around IX century until the XIII century. People who spread the teachings of Islam are known as "siak" which is those who belong to religious figures such as preachers, scholars, priests or bilal. Hasibuan (2010) mentions some names that have developed the teachings of Islam in Kerinci namely Siak Lengih in Koto Pandan, Siak Jelir in Siulak, Siak Rajo in Medang River, Siak Ali in Koto Beringin Semurup, Siak Sati in Koto Jelatang Hiang, Siak Baribut Sati in Koto Merantih Terutung, and Siak Ji (Haji), his tomb is in Lunang (Indrapura).

Before the arrival of Islam in Kerinci,
Kerinci society used to adhere to the teachings of animism and Hindu. This is still visible in traditional ceremonies such as Kenduri Sko, and a spirit summoning ceremony which they call as "orang gunung" through ritual songs and dances. Besides, the belief on spirit of after the death is transformed to the object or animal which is still attached to the present time.

\section{Traditional Ceremony / Arts}

People in Kerinci have various traditional ceremonies such as Kenduri Sko ceremony, asyeik ceremony, ngasap negri ceremony, balimau bathing ceremony, basantan bathing ceremony, tuhaun kayei ceremony, ayun luci ceremony, pilgrimage ceremony, mutual assistance/gotong royong (going down to the fields, building house, digging channels water, pulling the wood). All these ceremonies involve a lot of people indicating that Kerinci people still hold the principle of strong unity, mutual aid and assist each other as their proverbial " kerjo kecik bertabur arai, kerjo gedang bertabur urai “. Togetherness is also indicated by their proverb written on the gates into the city of Sungai Penuh, the capital of Kerinci district, which says 'sahalun suhak, salatuh bdei ' (Figure 7) and has the meaning of together, helping each other life.

The greatest traditional ceremony is "kenduri sko" which involves the whole population of the village where the ceremony is held. There are several goals of the big event of kenduri sko namely the inauguration or coronation of indigenous people like depati, rio, warrior, ninik mamak, cleaning and handing the heirlooms customary to be seen by the people of the village, binding 


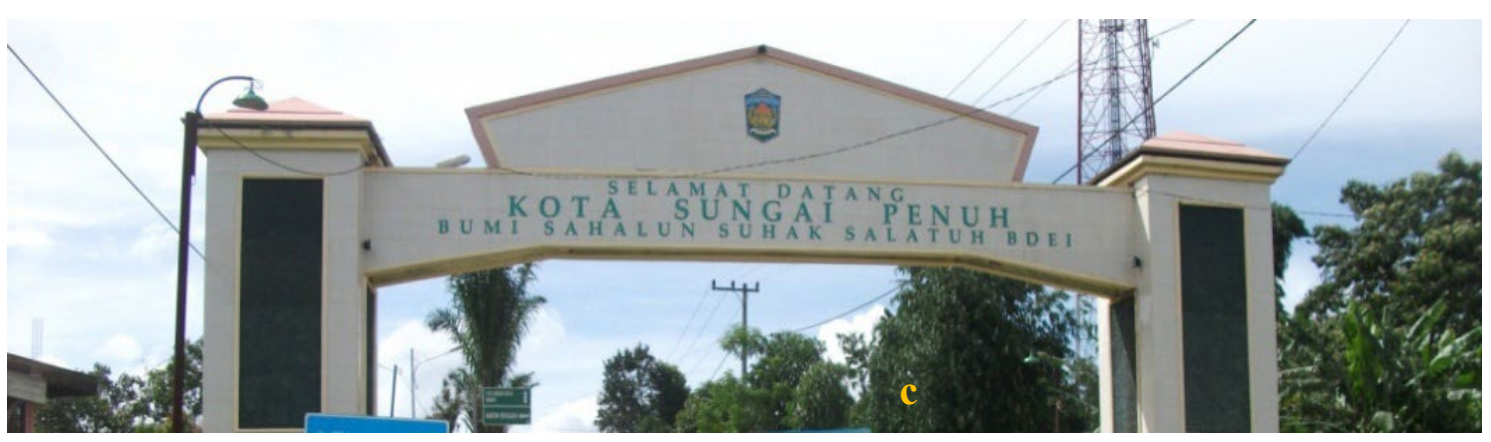

Figure 7: Welcoming Gate in Sungai Penuh City'bumi Sahalun suhak salatuh bdei’

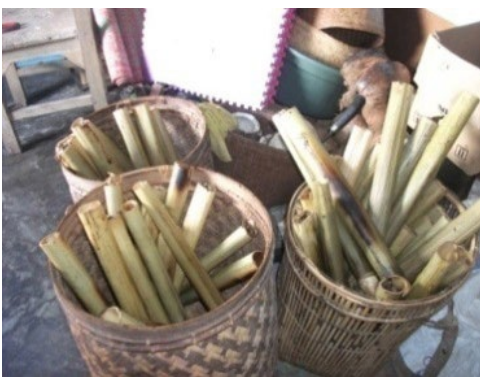

a

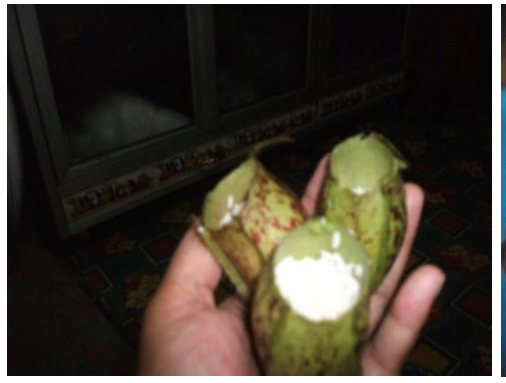

b

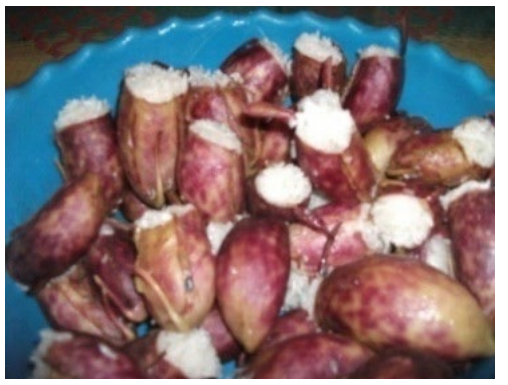

c

Figure 8 : Special Food kenduri sko: lemang (a) bamboo lemang (b) kancung beruk before being cooked (c) kancung beruk after being cooked

and establishing friendship, binding unity and integrity as well as readings of original manuscript of the comers to the local residents, especially the youth so they know where they come from

Kenduri sko is a ritual that is routinely performed each year, the time is after the harvest season. Based on direct observation in the field (coincidentally the time of data collection coincided with the kenduri sko ceremony in October 2013 which was held in Baru Lempur hamlet, so that researchers could witness the ceremony), ceremony of kenduri sko consists of series of activities beginning with a meeting of indigenous villages, a night of art, coronation of indigenous people and the script reading of the origin as well as cleaning the heirlooms.

On the art night, just before midnight, at 24.0o local time, 'summoning the spirits of the mountain' is done through traditional rituals led by traditional leaders in the form of song and dance. The dance that accompanies the call is tari tauah' (= dance tauah) danced by all members of the public who attend, especially the youth. During the 'calling the mountain spirit' ceremony, many dancers lose their consciousness. Not only dancers, the audience also experience that. This incident is believed by the public that the unconscious people are 'entered by the spirits of the mountain'.

Based on information from the field, 'Kenduri Sko ' is an act of gratitude for the abundant harvest from society to share with fellow citizens and also share to the 'penjaga alam (nature keeper)' and hope for the success of next year's harvest. All members of the community prepare a dish for visiting both houses of the village or people who come from another village. Typical food, which is always available during Kenduri Sko is lemang (Figure 8)

Lemang can be made by using bamboo gutters (Figure 8a) and plants 'pitcher' as the container, which is referred as 'Kancung Beruk' (Figure 8b). At first, Kenduri Sko was held once a year in each village, but in the last five years, Kenduri Sko is held sequentially between one village to other villages.

\section{CONCLUSION}

The portrait of Kerinci people shows that 
society is characterized as an indigenous people who have interacted with the natural environment for a long time. This special characteristic can be seen from the language, settlement patterns, traditional ceremonies and art, as well as the knowledge system for the management of natural resources. Kerinci community knowledge indicates that the existence of the forest in their village is very important. Kerinci community realizes that they inhabit the valley surrounded by mountains and hills, so the forest is a necessity. Forests are maintained to preserve the water source for their lives and shield them from the occurrence of landslides and flooding. Dynamics of changes in society lead to a form of adaptation pattern as seen on the original settlement pattern which has long house called Umah Larik into individual houses in a modern style. The habit to save the harvest in the barn is changed into saving it directly in the rice milling.

\section{ACKNOWLEDGEMENT}

My gratitude is addressed to Kerinci community that has given the necessary information, especially the people in Baru Lempur Hamlet, Lama Tamiai Hamlet, and Ulu Jernih Hamlet communities.

\section{REFERENCES}

Ali.Y.I. et al., 2005. Dalam Rasidin,M (ed).2005. Adat Basendi Syara' Sebagai Fondasi Membangun Masyarakat Madani di Kerinci. GP Press dan STAIN Kerinci Press, Sungai Penuh.

Aumeeruddy, Y., 1994. Local representations and management of agroforests on the periphery of Kerinci Seblat National Park Sumatra, Indonesia. People and Plants working Paper. UNESCO, Paris.

BPS Kabupaten Kerinci. 2012. Kerinci Dalam Angka 2012. Badan Pusat Statistik Kabupaten Kerinci. Kerinci.

Devi. 2012. Etnoekologi Masyarakat Kerinci. Thesis Universitas Indonesia.

Disparbud. 2003. Sastra Incung Kerinci. Kabupaten Kerinci.

Disparbud. 2004. Sejarah Perjuangan Rakyat Kerinci Mempertahankan Kemerdekaan Republik Indonesia 1945 - 1949. Perpustakaan Nasional: Katalog Dalam Terbitan (KDT) Pemerintah
Kabupaten Kerinci Dinas Pariwisata dan Kebudayaan.

Disparbud. 2004. Pesona Budaya Kabupaten Kerinci Provinsi Jambi, Upacara Tradisional Mandi Basantan. TMII

Genzuk. 2003. A Synthesis of Ethnographic Research Center for Multilingual, Multicultural Research. University of Southern California

Hasibuan, M.S.R., 2010. Karakteristik dan FaktorFaktor yang Mempengaruhi Lanskap Budaya Rumah Larik Limo Luhah di Kota Sungai Penuh, Kerinci, Provinsi Jambi. Skripsi. Bogor : Fakultas Pertanian, Institut Pertanian Bogor.

Hidayat. H., 2006. Perspeksi Stakeholders Dalam Pengelolaan Taman Nasional Kerinci Seblat di Era Otonomi Daerah. Jurnal Masyarakat Indonesia , 32(1).

Irawan, P., 2006. Penelitian Kualitatif dan Kuantitatif Untuk Ilmu-Ilmu Sosial. Jakarta, Departemen Ilmu administrasi Fakultas Ilmu Sosial dan Ilmu Politik Universitas Indonesia

Khaldum Ibn. 20oo. Muqaddimah. Pustaka Firdaus

Koentjaraningrat. 2009. Pengantar Ilmu Antropologi. Edisi Revisi 2009. Penerbit Rineka Cipta, Jakarta.

Lapau, B., 2012. Metode Penelitian Kesehatan : Metode Ilmiah Penulisan Skripsi, Tesis dan Disertasi. Yayasan Pustaka Obor Indonesia. Jakarta

Mangunjaya, F.M., 2005. Konservai Alam Dalam Islam. Yayasan Obor Indonesia, Jakarta.

Somad, K.A., 2003. Mengenal Adat Jambi Dalam Perspektif Modern. Dinas Pendidikan Provinsi Jambi, Jambi.

Salvador, T., 1999. Design Ethnography. Design Management Institute Issue Design Management Journal, 10(4), pp. 35-41

Spradley, J., 1997. Metode Penelitian Etnografi. Penerbit Tiara Wacana, Yogyakarta.

Tasman, A., 2013. Tambo Adat Alam Lekuk 50 Tumbi Lempur. Unpublished.

Watson, C.W., 1987. State and Society in Indonesia. Three papers.Occasional Paper No 8, Centre of South-East Asian Studies.74p. Canterbury, UK. University of Kent.

Watson, C.W., 1992. Kinship Property and Inheritance In Kerinci Central Sumatera. CSAC Monographs No 4 South-East Asian Series.255p. Canterbury UK, University of Kent.

Yakin, H.A.R., 1986. Menggali Adat Lama Pusaka Usang di Sakti Alam Kerinci. Unpublished.

Yasin, AK et al., 1999. Mengenal Hukum Adat Alam Kerinci serta Hak $\mathcal{E}$ Kewajiban Tengganai, Ninik Mamak Depati dalam membina persatuan kesatuan serta kerukunan hidup Desa dalam Kabupaten Kerinci. Makalah Hasil Musyawarah Adat Alam Kerinci Di Hamparan Besar Tanah Rawang.

Zakaria. I., 2012. Tambo Sakti Alam Kerinci. Unpub- 